\title{
Effect of Accounting Information System on Organisational Effectiveness: A Case Study of Selected Construction Companies in Ibadan, Nigeria
}

\author{
Onaolapo A. $\mathrm{A}^{1^{*}}$ and Odetayo T. $\mathrm{A}^{2}$ \\ ${ }^{I}$ Department of Accounting and Management, Ladoke Akintola University of Technology, Ogbomoso, Nigeria \\ ${ }^{2}$ Department of Accountancy, Osun State Polytechnic, Iree, Nigeria
}

\begin{abstract}
Automated Accounting Information System (AAIS) provides a tool for finance department to enhance organizational effectiveness especially in this era of global technology advancement. The study examined the effect of accounting information system on organizational effectiveness with special reference to selected construction firms in the Ibadan metropolis. Specifically, the study examined the effects of accounting information on quality of financial reports and decision -making. Purposive sampling technique was adopted in selecting a total of ten personnel from each of the selected companies as sample for the study. A hypothesis was formulated and both descriptive and inferential statistical tools were employed to analyze the data. The results show that accounting information system has effect on organizational effectiveness. Recommendations were subsequently made to both the managers of such organization and government on how the use of AAIS known as 'Contract Plus- Financial and Project Accounting' package software can enhance performance in Finance Departments.
\end{abstract}

Keywords: accounting, information system, organization, contract plus, global technology

\section{Introduction}

The emerging global economic scenario characterized by advancement in information technology, rapid changes in production processes, increased sophistry of the consumer, fierce market competition and unethical skimming activities of producers in the drive to survive the unpredictable and complex business dynamics, has brought to the fore the crucial role of accounting information in economic and business discourse especially in relation to administrative effectiveness (Curtis, 1995). As we all know, accounting speaks the language of business as it records all transactions of an individual firm or other bodies that can be expressed in monetary terms. Predicated on the going concept, accounting is the scheme and art of collecting, classifying, summarizing and communicating data of financial nature required to make economic decisions.

Accounting information is an ingredient in most, if not all, financial managerial decisions. In developed economies, these decisions are worth billions of dollars each year. In some cases, the decisions are lacking in quality. Consequently, if researches can improve decision making through improved information, society will benefit.

*Corresponding author. Email: adeonap@yahoo.com
Therefore, this paper argues that, there is a relationship between quality of Accounting information and effective administration. The paper examines the relationship between accounting information system and organizational effectiveness.

\section{Problem Statement}

Currently, the world and human life has been transformed from information age to a knowledge age (Curtis, 1995), and knowledge has been recognised as the most valuable asset. In fact, knowledge is not impersonal like money and does not reside in a book, a data bank or a software program (Choe, 1996). Choe believed that knowledge is always embodied in a person, taught and learned by a person, used or misused by a person. Accounting information is an unbiased tool for an effective administration. Poor accounting information jeopardizes administrative effectiveness, which makes managers malnourished administratively especially in Nigerian construction industry. The consequence of this has been the current distressed syndrome that Nigerian construction industries are facing. Huber (1999) stressed that companies must learn to manage their intellectual assets (i.e. knowledge) in order to survive and compete in the 'knowledge society'. Indeed, knowledge management is concerned with the exploitation and development of the knowledge assets 
(Chang, 2001). It is on these premises that the study wishes to examine the effect of quality of accounting information on the organization performance with special reference to selected construction companies in Ibadan.

\section{Literature Review}

Chang (2001) asserts that accounting information plays a significant role in enhancing organizational effectiveness in a global competitive environment. Doms, Jarmin and Klimek (2004) say that financial statements still remain the most important source of externally feasible information on companies. In spite of their widespread use and continuing advance, there is some concern that accounting practice has not kept pace with rapid economic and high technology changes which invariably affects the value relevance of accounting information. The importance of Chang's assertion is reinforced by massive accounting fraud in developed countries especially United States of America (USA), rapidly changing business environment and reports by some researchers that value relevance of accounting information has declined. However, a number of researchers claim that accounting information has not lost its value relevance.

Borthick and Clark (1990) believe that accounting exists because it satisfies a need primarily a need for information. In order to be relevant, accounting data must among others, be quick to respond to users' (particularly the investors) needs. Generally, investors are not in a situation to directly access the performance of companies in which they intend to invest. They usually depend on financial reports prepared by the management of such organizations. Financial report is one of the best sources of accounting information about a company. Financial reporting is an essential part of disclosure and helps investor to discover investment opportunities. The primary purpose of financial statements is to provide information concerning the financial situation of the company, its operational results, any changes of control in the company and cash flow.

\section{Organizational effectiveness}

Organizational effectiveness was succinctly defined by Daft (1983) as "the degree to which an organization realized its goals". However, Mondy, (1990) defined it aptly as "the degree to which an organization produce the intended output" As Daft rightly argued. Organizations pursue multiple goals, and such goals must be achieved in the face of competition limited resources, and disagreement among interest groups. Oguntimehin (2001) submitted that organizational effectiveness is the ability to produce desire results.

\section{Relationship between accounting information system} and organisational effectiveness

Ponemon and Nagida (1990) also asserts that the main reason for which accounting information is generated is to facilitate decision making. However, for financial reporting to be effective, among other requirements, it is relevant, complete and reliable. These qualitative characteristics require that the information must not be unfair nor has predisposition of favouring one party over the others. Accounting information should give a decision maker the capacity to predict future actions. It should also increase the knowledge of the users to identify similarities and differences in two type of information (Bolon, (1998). Therefore, reliable accounting information can be described as an essential pre-requisite for stock market growth. Based on the "engine of economic growth" potential of the stock market, developed nations do not toy with their Stock Markets and relevance of financial reporting.

Hunton, (2002) study, which investigated the relationship between automated accounting information system and organizational effectiveness; showed that there was strong relationship between accounting information system and organizational effectiveness, which means access to accounting information will lead to organizational effectiveness.

Several recent studies on value of accounting information for equity valuation, share price and earnings prediction have queried current financial reporting model in the developed world. The same issue can be raised in Nigeria about the value relevance of accounting numbers to investors. This assists the researcher to determine whether the result agrees or digresses from the previous studies.

In managing an organization and implementing an internal control system the role of accounting information system (AIS) is crucial. An important question in the field of accounting and management decision-making concerns the fit of AIS with organizational requirements for information communication and control. Although the information generated from an accounting information system can be effective in decision-making process, purchase, installation and usage of such a system are beneficial when the benefits exceed its costs. Huber, (1990) agrees that automated accounting information system aids decision making for management of orgnisations. Benefits of accounting information system can be evaluated by its impacts on improvement of decision- 
making process, quality of accounting information, performance evaluation, internal controls and facilitating company's transactions. Regarding the above five characteristics, the effectiveness of AIS is highly important for all the firms.

\section{Functions of accounting information system}

The main function of Accounting Information System (AIS) is to assign quantitative value of the past, present and future economics events. AIS through its computerized accounting system (Contract Plus) produces the financial statements namely income statements, balance sheets and cash flow statement. The system will process the data and transform them into accounting information during input, processing and output stages that will be used by a wide variety of users such as internal and external users (Wilkinson, 2000). Wilkinson noted that an effective Accounting Information System (AIS) performs several key functions throughout these three stages such as data collection, data maintenance, data Accounting Information Systems (AIS) and Knowledge Management; data control (including security) and information generation.

\section{Usage of information within accounting information} system

The construction projects undertaken by the company are divided according to the type of construction activities that comprised of five divisions, namely infrastructure, building, power, wastewater and oil and gas, where each project is treated as a separate company. The number of projects undertaken by each division depends on the contracts being awarded to the company. The sources of data originated from external parties such as client, subcontractors and suppliers.

The Project Accountants will work closely with the Quantity Surveyors to come out with the appropriate information as follows:

Client: The client's Quantity Surveyors (QSs) will evaluate work in progress (WIP) and come out with percentage of WIP to be agreed by both parties. Once agreed, Progress Billing Certificates (PBC) will be issued by Client's QSs, which a copy of it will be sent to head office for data processing.

Subcontractors: The Quantity Surveyors will evaluate subcontractor's work in progress (WIP) at site and come out with percentage of work in progress (WIP) to be agreed by both parties. Once agreed, Subcontractor Progress Certificate (SPC) will be issued by Quantity Surveyors and verified by Project Manager, which a copy of it will be sent to head office for data processing.

Suppliers: Quantity Surveyors and Project Accountants will ensure that the materials and machineries are delivered in good condition at construction site before delivery orders are accepted. The delivery orders will be attached to supplier's invoice and sent to Head Office for processing.

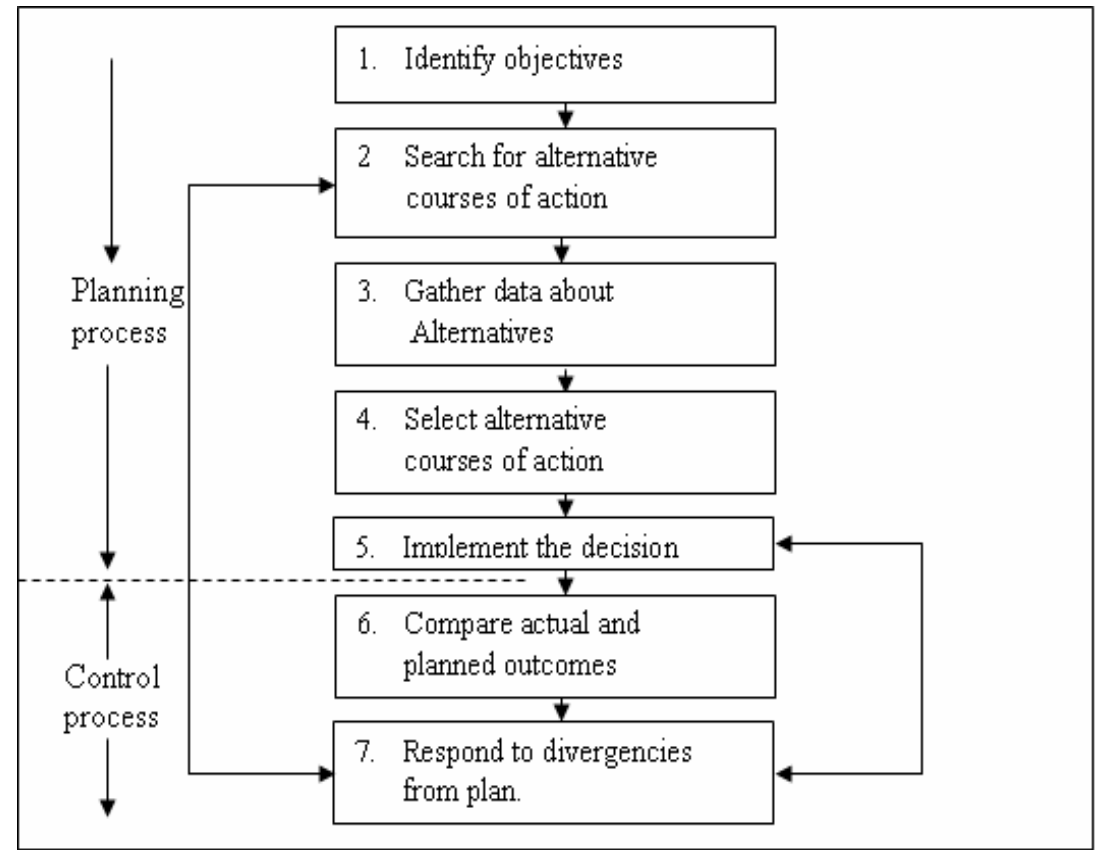

Figure 1. The decision making, planning and control process. 
The first five stages represent the decision-making or the planning process. Planning involves making choices between alternatives and is primarily a decision making activity. The final two stages represent the control process, which is the process of measuring and correcting actual performance to ensure that the alternative that are chosen and the plans for implementing them are carried out. Let us now consider each of the elements of the decisionmaking and control process.

i) Specify the Goals or Objectives of the Organization: Before good decisions can be made there must be some guiding aim or direction that will enable the decision-makers to assess the desirability of favouring one course of action over another. Hence, the first stage in the stage in the decisionmaking process should be to specify the goals or objectives of the organization.

ii) The Search for Alternative Courses of Action: The second stage in the decision-making model is a search for a range of possible courses of action (or strategies) that might enable the objectives to be achieved.

iii) Gather Data about Alternatives: When potential areas of activity are identified, management should assess the potential growth rate of the activities, the ability of the company to establish adequate market shares, and the cash flows for each alternative activity for various states of nature.

iv) Select Appropriate Alternative Courses of Action In practice, decision-making involves choosing between competing alternative courses of action and selecting the alternative that best satisfies the objective of an organization.

v) Implementation of the Decisions: Once alternative courses of action have been selected, they should be, implemented as part of the budgeting process. The budget is a financial plan for implementing the various decisions that management have made.

vi) Comparing Actual and Planned Outcomes and Responding to Divergences from Plan: The managerial function of control consists of the measurement, reporting and subsequent correction of performance in an attempt to ensure that the firm's objectives and plans are achieved.

\section{Construction industry in Nigeria}

Construction and related activities date back to time immemorial. It goes without saying that the industry is as important to the sustenance of the nation's economic growth as any of the other sector of the economy. A cursory look at the metro and cosmopolitan cities of Nigeria reflects the depth of exposure and activities in the construction industry within the years.
Construction design is a product of change in the society. It is an activity that encompasses assembling of parts to make a whole. Thus, the construction process starts from the process of developing a public or private infrastructure or site from planning, architectural work, the quantity surveying, landscaping to the actual mixing of concrete and cement, to the finishing of such completed structures by a real estate practitioner, or eventual commissioning in the case of road fly-overs and over head bridges. Interestingly, this process is as old as man. In the pre-colonial era, construction took place with tools such as mattocks, cutlasses, shovel, wheelbarrow, mud bricks and so on. Yet, the indigenous Nigerian societies had palaces, civic centres, recreational facilities and public utilities such as community wells and community halls, built with the use of these old tools and outdated construction techniques. The ancient walls of such cities like Kano and the old walls of the Oyo Empire still exist today as testimonies of the efficacy of traditional technology.

The dividends of Western expertise in the construction sector later became evident in the construction of monuments such as the Cocoa House in Ibadan, the popular Carter Bridge, Niger Bridge, Offa Bridge, the Onisha Bridge and several others. Also, the dredging of the Lagoon at Victoria Island, the building of the old secretariat at Ikoyi, the Dodan Barracks at Obalende, and even the construction of the first church cathedrals in Lagos, Abeokuta and Calabar. Virtually all of these were planned and designed by Western missioners and engineers.

These have no doubt charged the face of the nation and accelerated the growth of the construction industry. One name that has made so much impact in the Nigerian construction industry is Julius Berger Company; of course, other firms like the P. W (Nig.) Limited have made quantifiable impact too, clutching the major contracts in the industry, due to their accessibility to finance and government contacts. In view of the indigenization decree, many of the foreign firms have prominent Nigerian business moguls holding strategic positions on their boards. This is to the disadvantage of smaller firms wholly owned by Nigerian professional.

A major era in the history of the Nigerian construction industry is that which saw the movement of the federal seat of government from Lagos to Abuja. With the movement to Abuja, a new city had to be built; new office complexes for both private and public sector, new residential estates for the staff transferred to Abuja, new recreational facilities to cater for the masses and elites, new roads, among others. The urban and town planners went to work, designing and redesigning the Abuja map. What all these implied was more work in the construction 
sector, movement of heavy duty construction equipments to Abuja, the need for improved professionalism by the builders, architects and local engineers. Table 1 depicts some of the major construction companies in Nigeria

Table 1. List of some of the major construction companies in Nigeria.

\begin{tabular}{ll}
\hline Serial number & Names of the construction company \\
\hline 1 & Julius Berger Nigeria Plc,Ibadan \\
2 & Picolo Brunelli Construction Company, Ibadan \\
3 & Setraco Construction Company, Ibadan \\
4 & Bulletin Construction, Ibadan \\
5 & Reynolds Construction Company, Ibadan \\
6 & E Cappa Nigeria Plc, Ibadan \\
7 & P. W. Nigeria Limited, Ibadan \\
8 & Daewoo Construction Company, Ibadan \\
9 & Arab Contractors ,Ibadan \\
10 & Dantata \& Sawo Construction Company, Ibadan \\
11 & B. Stabilini Construction, Ibadan \\
\hline
\end{tabular}

\section{Challenges in the construction sector}

Like every other developing nation, the construction sector is confronted by a number of challenges. The constraints are which numerous include: Inadequate training of manpower; Low level of capital as a result of high bank rate; Low level of technology; Lack of maintenance culture; Designs need to be adapted to suit specific Nigerian needs climate and environment.

\section{Methodology}

The main objective of this study is to examine the effect of quality of accounting information system on the organization performance. While the specific objectives are: 1). To find out the effect of accounting information system on administrative effectiveness. 2). To examine how Accounting information system lead to better decision-making by Managers. The study covered five (5) randomly selected construction industries in Ibadan, Oyo state. The questionnaire technique was used in gathering relevant data from their financial accountant and site project manager respectively. The selected companies are: $P$. W. (Nig.) Limited; Reynolds Construction Company; Santa Monica Development Ltd; Architate Bulwarks; and
Dekit Construction Limited. Descriptive and inferential statistics tools were used to analyze the data with aid of statistical package for social science window (SPSS). Specifically analysis of variance (ANOVA) was use in testing the hypothesis. In the light of the above statement of problem the following hypothesis were formulated: H1: Accounting information system has significant effect on organizational effectiveness. Ho: Accounting information system has no significant effect on organizational effectiveness.

\section{Findings}

Thirty percent of the respondents were between the age of 20-44 years, forty percent were between 45-54 years and the remaining thirty percent were 55 years and above. Hence it is obvious that most of the accountants and site project managers are older and experienced. The respondents made up of four men and six women. This shows that majority of the accountants and site project managers are female with sixty percent. From the table 2 above it can be deduced that all accountants of selected construction companies are qualified chartered accountant and all site project managers are graduates with professional qualifications.

Table 2. Educational qualification.

\begin{tabular}{lcccc}
\hline & Frequency & Percent & Valid Percent & Cumulative percent \\
\hline ND/ACA & 1 & 10.0 & 10.0 & 10.0 \\
HND/ACA & 3 & 30.0 & 30.0 & 40.0 \\
BSC/ACA & 2 & 20.0 & 20.0 & 60.0 \\
MBA/ACA & 4 & 40.0 & 40.0 & 100.0 \\
Total & 10 & 100.0 & 100.0 & \\
\hline
\end{tabular}




\section{Statistical hypothesis}

Ho: Accounting information system has no significant effect on organisational effectiveness.
Hi: Accounting information system has significant effect on organisational effectiveness.

Table 3. ANOVA.

\begin{tabular}{|c|c|c|c|c|c|}
\hline Adjusted $\mathrm{R}=-0.077$ & \multicolumn{2}{|c|}{$\mathrm{R}=0.206^{*}$} & \multicolumn{3}{|l|}{$\mathrm{R}$ squared $=0.22$} \\
\hline & $\begin{array}{l}\text { Sum of } \\
\text { Squares }\end{array}$ & Df & Mean Square & $\mathrm{F}$ & Sig. \\
\hline Regression & 103.515 & & 12.939 & 7.354 & $0.018(a)$ \\
\hline Residual & 4.585 & & 1.759 & & \\
\hline Total & 108.100 & & & & \\
\hline \multicolumn{6}{|c|}{ Coefficients of regression line } \\
\hline Variable & \multicolumn{2}{|c|}{$\begin{array}{l}\text { Unstandardized } \\
\text { Coefficients }\end{array}$} & $\begin{array}{c}\text { Standardized } \\
\text { Coefficients }(\beta)\end{array}$ & $\mathrm{t}$ & Sig. \\
\hline Constant & 10.455 & & & 2.128 & 0.066 \\
\hline $\begin{array}{l}\text { Accounting } \\
\text { information }\end{array}$ & .138 & & 206 & .595 & 0.568 \\
\hline
\end{tabular}

*significant at 0.05 alpha level.

\section{Interpretation of the Results}

Null hypothesis goes thus; accounting information system has no significant effect on organisational effectiveness. From the result, it was discovered that there is positive effectiveness although the correlation is weak. Thus an increase in accounting information system will lead to an increase in organizational effectiveness. ' $F$ ' ratio (7.354) is significant this indicate that accounting information system is potent factor in determining organizational effectiveness. The model gives good account of dependent variable of organizational effectiveness on accounting information system as $\mathrm{R}^{2}$ due to regression (103.515). The coefficient of determinant of $\mathrm{R}=0.22$ this indicate that $22 \%$ variation in organizational effectiveness is accounted for by good accounting information system.

Therefore, null hypothesis is rejected, while alternative hypothesis is accepted, which state that Accounting information system has significant effect on organisational effectiveness. This result was supported by Borthick \& Clark (1990) in their research work, that for any organization to improve its productivity to the desired levels; they must be able to take cognizance of accounting information utmost importance.

\section{Conclusion and Recommendations}

The objective of this study was to examine the significant effect of accounting information system on organizational effectiveness with special reference to the selected construction industry in Ibadan metropolis. On the basis of the findings of this research paper, it could be concluded that accounting information systems has a significant effect on organizational effectiveness among the construction companies selected. The study found that good accounting information enhance administrative effectiveness.

The study also found that accounting information system leads to good financial reports and also leading to better decision- making. In addition the policy implication of the study is for International Accounting Standard Board (IASB) to adopt good accounting information system and make its application mandatory on construction industry.

This paper recommends that management of construction companies in Nigeria should make use of automated Accounting Information System (AIS) known as 'Contract Plus - Financial \& Project Accounting' package in their Finance Department. This software will generate financial data to be analysed by the accountants and subsequently used by top level of management for strategic decision making, thus, these managers could identify future opportunities and limitations face by the company and industry. In addition management of the companies should engage those that are computer literate and highly experienced, they should also be trained with latest information technology ascertained competitive effectiveness of the organization. Finally, government should create enabling environment this will allow workers to acquire training in computer usage. 


\section{References}

Borthick, A. F \& Clark, R. L. (1990). Making accounting information systems work: An empirical investigation of the creative thinking paradigm. Journal of Information Systems, 4(3), 48-62.

Boulianne, E. (2007). Revisiting fit between AIS design and performance with the analyzer strategic-type, International Journal of Accounting Information Systems, 8 (16) .

Bolon, M. (1998). Factors influencing the alignment of accounting information systems in small and medium sized Malaysian manufacturing firms. Retrieved from: http: find articles.com/p/ articles/mi.7097/is/1_2_2/ai_n28551322/pg 4/? Tag= contain:

Chang, Y. W. (2001). Contingency factors and accounting information system design in Jordanian companies. Journal of Accounting Information System, 8. 1-16.

Choe, J. M. (1996). The Relationships among performance of accounting information systems, influence factors, and evolution level of information systems, Journal of Management Information Systems, 12(4),215-239.

Curtis, G. (1995). Business information systems: Analysis, design and practice. Wokingham: Addison-Wesley Publishing Company.

Doms, M. E., Jarmin, R. S. \& Klimek, S. D. (2004). Information technology investment and firm performance in U.S. retail trade, Economics of Innovation and New Technology, 13(7), 595-613.

Daft, R. L. (1983) Organization theory and design, Minnesota, West Publishing Company.

El Louadi, M. (1998). The relationship among organization structure, information technology and information processing in small Canadian firms, Canadian Journal of Administrative Sciences, 15(2), 180-199.
Gordon, L. A. \& Miller, D. (1976). A contingency framework for the design of accounting information systems, Accounting, Organizations and Society, 1(1), 59-69.

Huber, G. P. (1990). A theory of the effects of advanced information technologies on organizational design, intelligence, and decision making, Academy of Management Review, 15(1), 47-71. IBIMA Business Review 12.

Hunton, J. E. (2002). Blending information and communication technology with accounting research, Accounting Horizons, $16(1), 55-67$.

Mondy, R.W, (1990), Management and organization behavior. Boston, Allyn and Bacon Publishers.

Oguntimehin, A. (2001). Teacher effectiveness: Some practical strategies for successful implementation of universal basic education in Nigeria, African Journal of Educational Management, 9(1) 151 - 161.

Ponemon, L. A. \& Nagoda, R. J. (1990). Perceptual variation and the implementation of accounting information systems: An Empirical investigation. Journal of Information System, 4(2), $1-14$.

Rahman, M. \& Halladay, M. (1988). Accounting information systems: Principles, applications and future directions. New Jersey: Prentice Hall.

Reneau, J. H. \& Grabski, S. V. (1987). A review of research in computer-human interaction and individual differences within a model for research in accounting information systems. Journal of Information Systems, 2(1), 33-53.

Wilkinson, J. W. (1993). Accounting information systems: Essential concepts and applications. Second Edition. New York: John Wiley \& Sons Inc.

Wilkinson, J. W., Cerullo, M. J., Raval, V. \& Wong-On-Wing, B. (2000). Accounting information systems: Essential concepts and applications. New York: John Wiley and Sons. 